\title{
EFEKTIVITAS SIBUMIL (APLIKASI DETEKSI RISIKO KEHAMILAN MANDIRI) BERBASIS ANDROID DI KOTA PEKALONGAN TAHUN 2021
}

\author{
Suparni $^{1)}$, Aslam Fatkhudin ${ }^{2)}$, Nina Zuhana ${ }^{3)}$ \\ ${ }^{1,3}$ Fakultas Ilmu Kesehatan, Universitas Muhammadiyah Pekajangan Pekalongan \\ ${ }^{2}$ Fakultas Teknik dan Ilmu Komputer, Universitas Muhammadiyah Pekajangan Pekalongan \\ Email: ${ }^{1}$ suparniluthfan@gmail.com, ${ }^{2}$ fatkhudin@gmail.com, ${ }^{3}$ ninazyhana@gmail.com
}

\begin{abstract}
The Covid-19 pandemic has caused restrictions on many activities, including pregnancy checks, because feared that pregnant women will contract the virus. So we need an innovation for pregnant women to know the risk of pregnancy to get the right treatment. This study aims to determine the effectiveness of the SiBumil application, which is an application to detect the risk of independent pregnancy. The population in this study were pregnant women with high risk in the Kramatsari Public Health Center, Pekalongan City as many as 103 as samples using the Krejcie and Morgan tables based on an error of 5\%. Primary data collection methods are carried out by direct assistance to pregnant women and distributing questionnaires. The results of the analysis using the alpha test with the Black box technique showed that the functions of all the menus in SiBumil were successfully executed. For the feasibility test using the usability test, an average of $84 \%$ was obtained, indicating that this application is very feasible to use. For differences in knowledge using the Wilcoxon test, $p$ value was obtained $0.000<\alpha(0.05)$ so it was concluded that there was a difference in knowledge before and after the use of SiBumil.
\end{abstract}

Keywords: SiBumil, pregnant women, android based, pregnancy risk detection

\section{PENDAHULUAN}

Skrining deteksi dini adanya faktor risiko secara proaktif pada semua ibu hamil merupakan upaya yang dilakukan sebagai pengenalan risiko ibu hamil. Salah satu upaya tersebut yaitu dengan skrining deteksi menggunakan metode Kartu Skor Poedji Rochjati (KSPR) yang dikeluarkan oleh Departemen Save Motherhood Rumah Sakit Umum Dokter Soetomo Surabaya. Penelitian yang dilakukan oleh Saraswati and Hariastuti (2017) dengan judul Efektivitas Kartu Skor Poedji Rochjati (KSPR) untuk Deteksi Risiko Tinggi pada Ibu Hamil di Puskesmas Ngumpak Dalem Kabupaten Bojonegoro diperoleh nilai $p$ value 0,001 yang berarti Kartu Skor Poedji Rochjati (KSPR) efektif untuk deteksi dini risiko tinggi pada ibu hamil.

Hasil studi pendahuluan yang dilakukan peneliti di Dinas Kesehatan Kota Pekalongan diperoleh data bahwa pada tahun 2020, Angka Kematian Ibu (AKI) sebanyak 152,4 per 100.000 kelahiran hidup (KH). Angka ini masih cukup tinggi jika dibandingkan dengan target SDGs (Sustainable Development Goals) tahun 2030 yaitu menurunkan angka kematian dan kesakitan salah satunya adalah Angka Kematian Bayi (AKB) sampai 12 per 1000 kelahiran hidup dan menurunkan AKI di bawah 70 per 100.000 kelahiran hidup (Kemenkes RI, 2015, hh 24-25). Pada bulan Desember 2020 terdapat 6.233 ibu hamil dengan kasus kehamilan dengan faktor risiko sebanyak $2.332(37,41 \%)$. Dari 14 Puskesmas yang ada di wilayah Kota Pekalongan, angka risiko tinggi yang tertinggi pada bulan Desember 2020 adalah di Puskesmas Kramatsari dengan jumlah ibu hamil sebanyak 285 dan ibu hamil dengan risiko tinggi sebanyak 143 (50\%). Berdasarkan data di atas maka dapat disimpulkan bahwa ada kemungkinan terjadinya penyulit atau komplikasi pada ibu maupun janin selama masa kehamilan, persalinan atau nifas yang diakibatkan oleh kehamilan dengan faktor risiko. 
Tingginya kasus kehamilan risiko ini, tenaga kesehatan tidak bisa menemukannya satu per satu sehingga dibutuhkan peran serta masyarakat dalam mendeteksi risiko kehamilannya, sehingga diperlukan suatu alat bantu untuk mendeteksi risiko kehamilan yang bisa digunakan oleh ibu hamil atau masyarakat secara mandiri yang hasil dari deteksi tersebut dapat diketahui atau diakses oleh Dinas Kesehatan Kota Pekalongan. Penelitian yang dilakukan oleh Ismayanty et al. (2019) dengan judul Pengaruh Aplikasi Deteksi Dini Risiko Kehamilan (DDILAN) terhadap Peningkatan Pengetahuan dan Sikap tentang Risiko Kehamilan diperoleh hasil adanya pengaruh aplikasi deteksi dini risiko kehamilan terhadap peningkatan pengetahuan dan sikap ibu hamil terhadap risiko kehamilan dengan nilai $p$ value 0,000 .

Aplikasi SiBumil adalah aplikasi yang disusun dengan tujuan utama untuk mengetahui status risiko kehamilan pada ibu hamil di wilayah Kota Pekalongan. Aplikasi sejenis sebelumnya sudah ada dan dikembangkan di Kabupaten Malang Jawa Timur. Kelebihan dari SiBumil ini adalah berbasis database di mana data ibu hamil yang sudah mengisi SiBumil ini akan langsung masuk ke website Dinas Kesehatan Kota Pekalongan dengan berkoordinasi dengan Dinas Komunikasi dan Informatika (Dinkominfo) Kota Pekalongan sehingga dapat diaplikasikan dengan baik. Tambahan lain dari SiBumil ini adalah menampilkan alamat dan call center Puskesmas dan RS di wilayah Kota Pekalongan serta informasi seputar kesehatan ibu dan bayi di masa pandemi Covid-19.

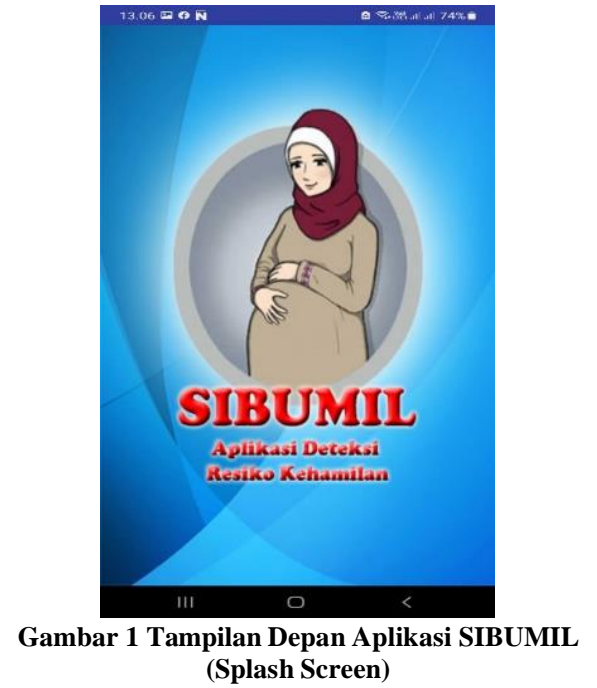

Gambar 1 merupakan gambar splash screen yaitu tampilan pertama saat aplikasi SiBumil dijalankan. Halaman ini hanya tampil selama 3 detik saja sebagai informasi mengenai aplikasi SiBumil.

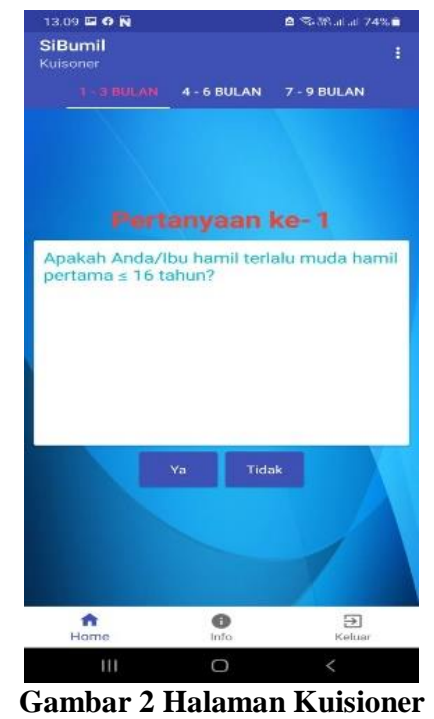

Setelah tampilan splash screen, berikutnya aplikasi akan mengarahkan ke halaman utama atau halaman kuesioner yang tampilannya seperti tampak pada gambar 2 di atas. Halaman kuesioner ini berisi tiga sub halaman berdasarkan periodesasi usia kehamilan, yaitu sub halaman $1-3$ bulan, $4-6$ bulan dan $7-9$ bulan. Setelah responden menjawab sejumlah pertanyaan kuesioner yang ada pada halaman kuesioner (20 pertanyaan), berikutnya responden akan diarahkan ke halaman hasil kuisioner. 
Uji usability biasa digunakan oleh beberapa peneliti untuk menilai kelayakan aplikasi yang dibuatnya, di antaranya Pengujian Usability untuk Meningkatkan Antarmuka Aplikasi Mobile myUMMStudent. Aplikasi myUMMStudent merupakan aplikasi informasi akademik mahasiswa Universitas Muhammadiyah Malang. Pengujian usability ini menggunakan metode kuesioner untuk memperoleh hasilnya dengan menggunakan Skala Likert yang melibatkan 30 responden. Pertanyaan dibagi ke dalam 4 aspek, yaitu learnability, flexibility, effectiveness dan attitude. Hasil pengujian usability aplikasi myUMM mencapai 81,62\% menunjukan bahwa aplikasi myUMM sangat layak digunakan oleh pengguna sebagai media informasi (Riyadi, 2019).

Melihat fakta-fakta tersebut, maka penulis tertarik untuk membuat sebuah aplikasi berbasis Android yang dapat digunakan oleh ibu hamil untuk mengetahui faktor risiko dalam kehamilannya dan rekomendasinya serta lokasi fasilitas kesehatan yang tersedia di Kota Pekalongan.

\section{METODE PENELITIAN}

Android adalah sistem operasi dan platform pemrograman yang dikembangkan oleh Google untuk smartphone dan perangkat seluler lainnya (seperti tablet). Android bisa berjalan di beberapa macam perangkat dari banyak produsen yang berbeda. Sebagai platform perangkat seluler paling populer di dunia, Android mendukung ratusan juta perangkat seluler lebih dari 190 negara di seluruh dunia. Android dapat dikembangkan sendiri oleh para penggunanya, karena sifatnya yang opensource yaitu dengan menggunakan Android Software Development Kit (SDK). SDK ini terdiri dari serangkaian alat development menyeluruh yang menyertakan debugger, pustaka perangkat lunak kode pratulis, emulator perangkat, dokumentasi, kode contoh, dan tutorial. Selain itu, untuk mengembangkan aplikasi menggunakan SDK, dapat juga dilengkapi dengan bahasa pemrograman Java dan file Extensible Markup Language $(X M L)$.
Jenis penelitian ini adalah research and development dengan empat langkah untuk merancang Aplikasi Deteksi Risiko Kehamilan berbasis Android (Notoatmodjo, 2014). Populasi dalam penelitian ini ibu hamil dengan faktor risiko yang berada di wilayah Puskesmas Kramatsari Kota Pekalongan sebanyak 143 ibu hamil. Teknik pengambilan sampel dalam penelitian ini menggunakan tabel Krejcie dan Morgan yang didasarkan atas kesalahan 5\% yaitu sebanyak 103 ibu hamil yang memenuhi kriteria inklusi dan eksklusi. Alat ukur yang digunakan untuk melakukan pengujian aplikasi menggunakan cek list yang langsung diisi saat pendampingan pada ibu hamil. Untuk uji kelayakan menggunakan kuesioner dengan skala Likert yang berisi serangkaian pernyataan yang telah dikelompokkan dalam beberapa aspek usability dengan 14 pertanyaan yang memenuhi empat kriteria yaitu : learnability, fleksibility, effectiveness, dan attitude. Instrumen untuk mengetahui perbedaan pengetahuan sebelum dan sesudah penggunaan SiBumil dengan menggunakan kuesioner yang terdiri dari 15 pertanyaan. Langkah awal pengambilan data adalah melakukan pendampingan langsung pada 20 orang ibu hamil untuk mengoperasikan semua fungsi yang ada pada SiBumil dan hasilnya dituangkan ke dalam cek list penilaian. Penelitian berikutnya dilakukan pada 103 ibu hamil dengan mengirimkan kuesioner sebelum penggunaan SiBumil melalui Google Form dan meminta responden untuk mengisi. Setelah kuesioner selesai diisi kemudian dikirimkan file SiBumil dan meminta pasien untuk mengunduh SiBumil tersebut di HP Android responden. Responden diberikan edukasi bagaimana cara mengoperasikan SiBumil dan diminta untuk mengisi pertanyaan yang ada di SiBumil serta mempelajari materi yang ada di SiBumil pada menu info selama tujuh hari. Setelah penggunaa SiBumil selama tujuh hari diberikan kembali kuesioner sesudah penggunaan SiBumil dan meminta responden untuk mengisi kembali. Proses pengambilan data penelitian dibantu oleh enumerator yang sebelumnya sudah dilakukan persamaan persepsi antara tim peneliti dengan enumerator data. Analisis data yang digunakan untuk pengujian sistem dengan 
uji alpha dengan teknik black box. Analisis deskriptif yang digunakan adalah untuk menguji kelayakan usability analisis deskriptif persentase. Untuk pengujian perbedaan 2 kelompok data berpasangan tetapi data berdistribusi tidak normal menggunakan uji non parametris yaitu uji wilcoxon.

\section{HASIL DAN PEMBAHASAN}

\subsection{Karakteristik Responden}

\subsubsection{Berdasarkan Usia}

Berdasarkan karakteristik responden, usia ibu hamil dalam penelitian ini paling banyak berada pada rentang usia reproduksi sehat (2035 tahun) sebanyak $91(88,3 \%)$.

Tabel 1 Responden Berdasarkan Usia

\begin{tabular}{llr|r|r}
\hline \multicolumn{5}{c}{ UMUR } \\
\hline \multirow{3}{*}{ Valid } & \multicolumn{2}{c}{ Frequency } & $\begin{array}{c}\text { Valid } \\
\text { Percent }\end{array}$ & \multicolumn{2}{c}{$\begin{array}{c}\text { Cumulative } \\
\text { Percent }\end{array}$} \\
\cline { 2 - 5 } & $<20$ & 1 & 1.0 & 1.0 \\
\cline { 2 - 5 } & $20-35$ & 91 & 88.3 & 89.3 \\
\cline { 2 - 5 } & $>35$ & 11 & 10.7 & 100.0 \\
\cline { 2 - 5 } & Total & 103 & 100.0 & \\
\hline
\end{tabular}

Hal ini dapat dikatakan bahwa rata rata respoden yang mengggunakan HP Android adalah di usia muda. Sesuai dengan penelitian Miura Prayogi (2016) yaitu responden yang mayoritas usia muda merupakan risiko terdekat dengan adiksi smartphone. Umumnya semakin dini usia seseorang, perkembangan mental yang terbentuk belum sempurna sehingga kecenderungan adiksi terhadap smartphone lebih tinggi.

\subsubsection{Berdasarkan Pendidikan}

Sebagian besar tingkat pendidikan ibu hamil memiliki pendidikan dasar yaitu SD sebanyak 24 (23\%) dan SMP sebesar 33 (32\%). Status Pendidikan yang rendah lebih mudah mengalami adiksi terhadap penggunaan smartphone. Individu dengan status Pendidikan rendah tidak mempunyai pengetahuan cukup untuk mengontrol diri dalam penggunaan smartphone, sama halnya dengan adiksi terhadap games (Miura Prayogi, 2016).

Tabel 2 Responden Berdasarkan Tingkat Pendidikan

\begin{tabular}{llr|r|r}
\hline \multicolumn{4}{c}{ PENDIDIKAN } \\
\hline & \multicolumn{2}{c}{ Frequency } & $\begin{array}{c}\text { Valid } \\
\text { Percent }\end{array}$ & $\begin{array}{c}\text { Cumulative } \\
\text { Percent }\end{array}$ \\
\hline \multirow{5}{*}{ Valid } & TAMAT SD & 24 & 23.3 & 23.3 \\
\cline { 2 - 5 } & TAMAT SMP & 33 & 32.0 & 55.3 \\
\cline { 2 - 5 } & TAMAT SMA & 35 & 34.0 & 89.3 \\
\cline { 2 - 5 } & TAMAT PT & 11 & 10.7 & 100.0 \\
\cline { 2 - 5 } & Total & 103 & 100.0 & \\
\hline
\end{tabular}

Studi yang dilakukan Santoso, (2013) menunjukkan semakin rendah tingkat pendidikan maka semakin tinggi kecenderungan terhadap adiksi games. Semakin rendah status pekerjaan, kecenderungan mengalami adiksi smartphone lebih tinggi.

\subsubsection{Berdasarkan Pekerjaan}

Sebagian besar ibu hamil dalam penelitian ini berprofesi sebagai ibu rumah tangga sebesar $71(68,9 \%)$.

Tabel 3 Responden Berdasarkan Pekerjaan

\begin{tabular}{llr|r|r}
\hline \multicolumn{5}{c}{ PEKERJAAAN } \\
\hline \multirow{5}{*}{ Valid } & Frequency & $\begin{array}{c}\text { Valid } \\
\text { Percent }\end{array}$ & $\begin{array}{c}\text { Cumulative } \\
\text { Percent }\end{array}$ \\
\cline { 2 - 5 } & IRT & 71 & 68.9 & 68.9 \\
\cline { 2 - 5 } & SWASTA & 30 & 29.1 & 98.1 \\
\cline { 2 - 5 } & PNS & 2 & 1.9 & 100.0 \\
\cline { 2 - 5 } & Total & 103 & 100.0 & \\
\hline
\end{tabular}

\subsection{Uji Alpha dengan Teknik Black box}

Hasil dari uji alpha dengan menggunakan teknik black box untuk setiap menu yaitu splash screen, halaman utama/halaman kuesioner, halaman hasil kuesioner, halaman form laporkan/input data, halaman info dan halaman about us dapat digunakan dengan baik. Dari 20 responden yang dilakukan pendampingan diminta untuk membuka setiap aplikasi yang ada di SiBumil.

Beberapa penelitian yang menggunakan uji alpha dengan teknik black box testing untuk menguji suatu aplikasi apakah bisa berjalan dengan baik atau tidak di antaranya penelitian dengan judul Pengujian Sistem Informasi $E$ Commerce Usaha Gudang Cokelat Menggunakan Uji Alpha dan Beta. Aplikasi ECommerce pada penelitian tersebut terdapat 4 halaman yang diuji menggunakan uji alpha, yaitu halaman Navigation Home Page, Navigation Page Login, Navigation Page Pesanan dan Navigation Logout Session, yang kesemuanya setelah dicoba semua fitur oleh para responden ternyata hampir semuanya berhasil berjalan dengan baik sesuai yang diharapkan, kecuali satu fitur yaitu pada halaman Navigation Logout Session tidak menampilkan pesan error pada customer yang tidak melakukan login (Suandi, Khasanah and Retnoningsih, 2017). 


\subsection{Uji Kelayakan SiBumil}

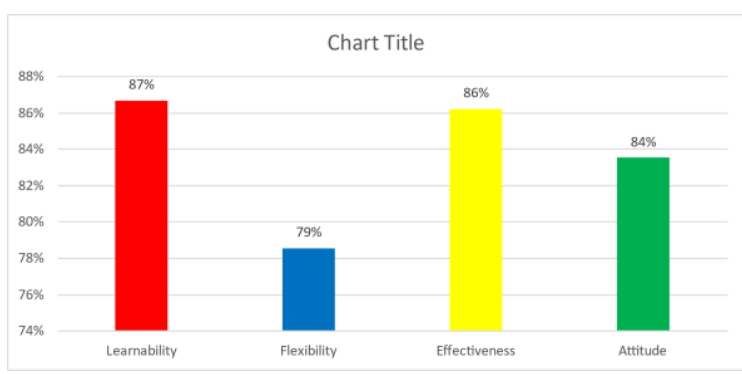

Gambar 1 Diagram Tabel Uji Kelayakan

Berdasarkan diagram di atas dapat dilihat bahwa rata-rata nilai untuk learnability $=87 \%$, flexibility $=79 \%$, effectiveness $=86 \%$ dan attitude $=84 \%$. Berdasarkan nilai flexibility menunjukkan bahwa aplikasi ini layak untuk digunakan dan berdasarkan nilai learnability, effectiveness dan attitude menunjukkan bahwa aplikasi ini sangat layak digunakan oleh pengguna sebagai alat bantu untuk membantu mendeteksi risiko melahirkan bagi ibu hamil.

Penelitian lain yang menggunakan uji usability untuk menilai aplikasi yang dibuatnya adalah Pengujian Usability Untuk Meningkatkan Antarmuka Aplikasi Mobile MBreakfast Nutrition. Uji usability pada penelitian ini juga menggunakan lembar kuisioner dengan skala Likert untuk memperoleh data dari responden yang berjumlah 20 orang siswa kelas 6 pada SD Negeri Bantarjati 6 Kecamatan Bogor Utara. Pada penelitian ini, pertanyaan dibagi ke dalam 3 aspek, yaitu efisiensi, efektivitas dan kepuasan pengguna terhadap aplikasi. Hasil pengujian mencapai angka $91,1 \%$ yang menunjukkan bahwa aplikasi tersebut dapat diterima oleh pengguna (Nurhadryani, Sianturi and Hermadi, 2013)

\subsection{Hasil Uji Pengetahuan}

Tabel 4 Test of Normality Data Pengetahuan

\begin{tabular}{|c|c|c|c|c|c|c|}
\hline \multirow{2}{*}{ 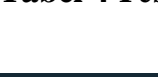 } & \multicolumn{3}{|c|}{-Smirnov ${ }^{a}$ Kolmogorov } & \multicolumn{3}{|c|}{ Shapiro-Wilk } \\
\hline & Statistic & $d f$ & Sig. & Statistic & $d f$ & Sig. \\
\hline TAHUSEB & .131 & 103 & .000 & .970 & 103 & .018 \\
\hline TAHUSSD & .106 & 103 & .006 & .963 & 103 & .006 \\
\hline
\end{tabular}

Uji normalitas data pada penelitian ini menggunakan uji kolmogorov smirnov dikarenakan jumlah sampel > 50. Dari tabel di atas dapat disimpulkan bahwa dua kelompok data tidak berdistribusi normal karena nilai sig $<0,05$. Setelah dilakukan uji normalitas pada penelitian ini maka dilanjutkan untuk melakukan uji perbedaan. Uji perbedaan untuk kelompok data yang berdistribusi tidak normal menggunakan analisa non parametrik yaitu $u j i$ Wilcoxon.

Tabel 5 Hasil Uji Wilcoxon Signed Rank Test untuk Pengetahuan

\begin{tabular}{llr|r|r}
\hline \multicolumn{5}{c}{ Ranks } \\
\hline & $\mathrm{N}$ & $\begin{array}{c}\text { Mean } \\
\text { Rank }\end{array}$ & \multicolumn{1}{c}{$\begin{array}{c}\text { Sum of } \\
\text { Ranks }\end{array}$} \\
\hline TAHU & Negative Ranks & $10^{\mathrm{a}}$ & 38.00 & 380.00 \\
\cline { 2 - 5 } SSD - & Positive Ranks & $89^{\mathrm{b}}$ & 51.35 & 4570.00 \\
\cline { 2 - 5 } TAHU & Ties & $4^{\mathrm{c}}$ & & \\
\cline { 2 - 5 } SEB & Total & 103 & & \\
\hline a. TAHUSSD < TAHUSEB & & & \\
b. TAHUSSD > TAHUSEB & & & \\
c. TAHUSSD = TAHUSEB & & &
\end{tabular}

Negatif ranks/sampel dengan nilai kelompok pengetahuan sebelum perlakuan yang lebih kecil dari nilai kelompok pengetahuan sesudah perlakuan adalah sebanyak 10 sampel. Positive rank/sampel dengan nilai kelompok pengetahuan sebelum perlakuan lebih besar dari nilai kelompok pengetahuan sesudah perlakuan adalah sebanyak 89 sampel. Ties/nilai kelompok pengetahuan sebelum yang sama besarnya dengan kelompok sesudah perlakuan sebanyak 4 sampel.

Tabel 6 Hasil Analisis Perbedaan Pengetahuan sebelum dan sesudah penggunaan SiBumil

\begin{tabular}{lr}
\hline \multicolumn{2}{c}{ Test Statistics $^{\mathrm{a}}$} \\
\hline & $\begin{array}{c}\text { TAHUSSD - } \\
\text { TAHUSEB }\end{array}$ \\
\hline$Z$ & $-7.353^{\mathrm{b}}$ \\
\hline Asymp. Sig. (2-tailed) & .000 \\
\hline a. Wilcoxon Signed Ranks Test \\
b. Based on negative ranks.
\end{tabular}

Tabel di atas merupakan uji wilcoxon menggunakan SPSS. Dapat diketahui bahwa $p$ value uji wilcoxon 0,000 lebih kecil dari $\alpha$ $(0,05)$ sehingga dapat disimpulkan bahwa terdapat perbedaan pengetahuan sebelum (pre test) dan sesudah (post test) penggunaan SiBumil.

Hasil penelitian ini juga sejalan dengan Pratiwi Putu Irma (2021) yaitu hasil penggunaan aplikasi berbasis web memberikan pengaruh terhadap peningkatan pengetahuan kader posyandu terhadap deteksi dini stunting, hal ini berarti terdapat perbedaan yang nyata 
terhadap pengetahuan kader posyandu pada saat sebelum diberikan intervensi dan setelah diberikan intervensi. Dalam pengetahuan, pengalaman merupakan hal terpenting dalam peningkatan pengetahuan yang lebih baik, menurut Soekidjo Notoatmodjo (2010) bahwa pengalaman dapat diperoleh dari pengalaman sendiri atau orang lain. Pengalaman yang sudah diperoleh dapat memperluas pengetahuan seseorang. Pengalaman yang dapat mempengaruhi pengetahuan tidak hanya dilihat dari pengalaman yang posistif saja, tetapi pengalaman yang negatifpun membuat pengetahuan dapat meningkat.

Mobile Health (M-Health) merupakan suatu bentuk inovasi dan kemajuan dari teknologi e-health yang dimanfaatkan dalam dunia kesehatan, inovasi ini diharapkan dapat menjangkau seluruh lapisan masyarakat dengan menggunakan piranti online atau sistem pra bayar dengan menggunakan device/media komunikasi yang sangat dekat dengan manusia seperti handphone, tablet dan internet (WHO, 2011). Teknologi mobile membantu petugas kesehatan masyarakat dalam pengumpulan data, pesan pengingat, menfasilitasi pendidikan kesehatan dan sebagai media komunikasi dalam masyarakat (Braun et al., 2013) yang sejalan dengan hasil penelitian Coughlin et al. (2016) yaitu penggunaan aplikasi smartphone berpotensi digunakan sebagai sarana promosi kesehatan yang dapat meningkatkan pengetahuan dan sikap seseorang.

Penelitian ini juga didukung oleh penelitian Irawati, Ahmad dan Syarif (2018) yang menemukan optimalisasi sistem pakar berbasis mobile meningkatkan efektivitas dan deteksi dini risiko preeklamsia oleh bidan dan sistem pakar berbasis mobile ini mampu mendeteksi secara dini risiko preeklamsia pada ibu hamil. Penelitian Ismayana, Nontji W, (2020) menegaskan bahwa aplikasi berbasis mobile konsisten pertanyaan yang berkaitan dengan faktor risiko kehamilan rata-rata lebih efektif digunakan dalam deteksi dini faktor risiko kehamilan dibandingkan dengan buku KIA ditinjau dari segi aspek kemudahan, kecepatan, keamanan dan keakuratan data

\section{KESIMPULAN}

Simpulan yang dirumuskan dalam penelitian ini adalah aplikasi SiBumil dengan uji alpha menggunakan teknik black box berfungsi dengan baik dan benar. Aplikasi SiBumil layak digunakan sebagai alat bantu untuk deteksi risiko kehamilan di wilayah Kota Pekalongan, dan ada perbedaan pengetahuan ibu hamil sebelum dan sesudah menggunakan aplikasi deteksi risiko kehamilan. Hasil penelitian ini memberikan implikasi terhadap peningkatan pengetahuan ibu hamil mengenai risiko tinggi kehamilan. Selama ini kehamilan risiko tinggi masih menjadi masalah dan menjadi salah satu faktor terjadinya kematian pada ibu. Dengan adanya SiBumil ini akan meningkatkan deteksi dini risiko tinggi secara mandiri oleh ibu hamil dan meningkatkan pengetahuan ibu hamil.

Saran untuk Bappeda Kota Pekalongan adalah memanfaatkan hasil penelitian aplikasi SiBumil ini sebagai alat bantu untuk deteksi risiko kehamilan di wilayah Kota Pekalongan dengan rekomendasi kepada Dinas Kesehatan Kota Pekalongan. Untuk Dinas Kesehatan Kota Pekalongan hasil penelitian ini dapat disosialisasikan penggunaan SiBumil kepada Puskesmas, tenaga kesehatan khususnya bidan serta masyarakat di wilayah Kota Pekalongan agar dapat menggunakan SiBumil untuk membantu deteksi risiko kehamilan secara mandiri agar dapat menurunkan kematian ibu di wilayah Kota Pekalongan.

\section{REFERENSI}

Braun, R. et al. (2013) 'Community Health Workers and Mobile Technology: A Systematic Review of the Literature', PLoS ONE, 8(6), pp. 4-9. doi: 10.1371/journal.pone.0065772.

Coughlin, S. S. et al. (2016) 'A Review of Smartphone Applications for Promoting Physical Activity.', Jacobs journal of community medicine, 2(1), pp. 1-14. Available at: http://www.ncbi.nlm.nih.gov/pubmed/270 34992\%0Ahttp://www.pubmedcentral.nih. gov/articlerender.fcgi?artid=PMC4811195. Irawati, Ahmad, M. and Syarif, S. (2018) '( Mobile Based Preeclampsia Detection 
System Optimization Expert )

Karakteristik Ibu Hamil yang Datang Ber-

, Jurnal Ners dan Kebidanan, 5(2), pp. $159-162$. doi:

10.26699/jnk.v5i2.ART.p159.

Ismayana, Nontji W, S. S. (2020) 'PERBANDINGAN EFEKTIVITAS APLIKASI SMART CONTINUITY OF CARE (MONSCA) DAN BUKU KIA TERHADAP DETEKSI DINI FAKTOR RISIKO KEHAMILAN Comparison of Effectiveness between Smart Continuity (Monsca) with KIA Book on Early Detection of Pregnancy Risk Factors', Jurnal Riset Kesehatan Poltekes Depkes Bandung, pp. 869-876. doi: 10.34011/juriskesbdg.v12i2.866.

Ismayanty, D. et al. (2019) 'Pengaruh aplikasi deteksi dini risiko kehamilan ( DDILAN ) terhadap peningkatan pengetahuan dan sikap tentang risiko kehamilan to improvement knowledge and attitudes about the risk of pregnancy', Jsk, 5(71), pp. 129-133.

Miura Prayogi, R. E. (2016) 'JURNAL PERKOTAAN Juni 2016 Vol. 8 No. 1', 8(1), pp. 1-11.

Notoatmodjo, S. (2014) Metode Penelitian Kesehatan. Jakarta: PT Rineka Cipta.

Nurhadryani, Y., Sianturi, S. K. and Hermadi, I. (2013) 'Pengujian Usability untuk Meningkatkan Antarmuka Aplikasi Mobile Usability Testing to Enhance Mobile Application User Interface', Jurnal Ilmu Komputer Agri-Informatika, 2(2010), pp. 83-93.

Pratiwi Putu Irma, S. N. N. A. D. (2021) 'pISSN: 2086-0722 eISSN: 2549-6603', Jurnal Kesehatan Al Irsyad, 14(Penggunaan Aplikasi Berbasis Web Pada pengetahuan Kader Posyandu Mengenai Deteksi Dini Stunting), pp. 103112.

Riyadi, N. R. (2019) 'PENGUJIAN USABILITY MENINGKATKAN ANTARMUKA UNTUK APLIKASI MOBILE myUMM STUDENTS', Sistemasi, 8(1), p. 226. doi: 10.32520/stmsi.v8i1.346.

Santoso, B. (2013) 'Pengaruh Perceived
Usefulness, Perceived Ease of Use, Dan Peceived Enjoyment Terhadap Penerimaan Teknologi Informasi Maret', Jurnal Studi Akuntansi Indonesia, (1998), pp. 1-15.

Saraswati, D. E. and Hariastuti, F. P. (2017) 'Efektivitas Kartu Skor Poedji Rochjati (KSPR) Untuk Deteksi Resiko Tinggi Pada Ibu Hamil Di Puskesmas Ngumpakdalem Kabupaten Bojonegoro', Jurnal Ilmu Kesehatan MAKIA, 5(1), pp. 28-33. doi: 10.37413/jmakia.v5i1.35.

Soekidjo Notoatmodjo (2010) Ilmu Perilaku Kesehatan. Jakarta: EGC.

Suandi, A., Khasanah, F. N. and Retnoningsih, E. (2017) 'Pengujian Sistem Informasi Ecommerce Usaha Gudang Cokelat Menggunakan Uji Alpha dan Beta', Information System for Educators and Professionals, 2(1), pp. 61-70. Available at:

https://media.neliti.com/media/publications /234474-pengujian-sistem-informasi-ecommerce-us-2bea597f.pdf.

WHO (2011) mHealth New Horizons For Health Through Mobile Technologies. 